\title{
The Aesthetics of Sundanese Traditional Design Case study: Rice Containers Design
}

\author{
Jamaludin \\ Department of Interior Design, National Institute of Technology (ITENAS), \\ Jalan PHH. Mustafa No. 23, Bandung 40124, Indonesia \\ Email: jamal@itenas.ac.id
}

\begin{abstract}
The traditional design that is still made and exists today is a legacy from mythical culture period. That is to say that it has its own aesthetical concept that is different from modern aesthetics. Some of the traditional designs in Sundanese society is the rice containers that come in different form depends on the rice condition. The design of a traditional rice container in Sundanese culture is made in basic shapes, such as square, circle and triangle or configuration of the basic shapes resulted in a beautiful design. The rice containers mostly made of woven bamboo. Uniquely, these visual basic shapes also found in proverbs and idioms in Sundanese language as a symbol of perfection of conduct. Square symbolizes attitude or behavior, circle is for belief or faith, and triangle represents a holy place. Rice in traditional community such as Baduy in Banten has a connection with the myth of the goddess of rice. Thus, Sundanese traditional culture and society highly respect the rice. This is one of the reasons why the traditional rice containers are designed in those form. This study has come to a conclusion that traditional design made is not merely to fulfill utility needs but also to represent the Sundanese macrocosm.
\end{abstract}

Keywords: rice container; shape and form; Sundanese; traditional design.

\section{$1 \quad$ Introduction}

As a cultural product, design has its own value system made by a certain community. Traditional design that is still made and used today, such as that in Sundanese traditional society, is a legacy from mythical culture period. According to Sumardjo [1], mythical culture concept is the unity between microcosm and macrocosm, between immanent and transcendent, between human world and spirit world or god. This cosmos unity concept can only acquired by understanding the belief of local society who produces the design object. Design objects from mythical culture based-on the way of thought that human united with the nature outside themselves. The concepts or thought in mythical culture period is different from ontological way of thinking that created modern design. Thus the mythical world has its own aesthetic that differs with modern aesthetic. In other words, traditional design created not

Received July $5^{\text {th }}, 2010$, Revised October $2^{\text {th }}, 2013$, Accepted for publication November $8^{\text {th }}, 2013$.

Copyright (C) 2013 Published by LPPM ITB, ISSN: 1978-3078, DOI: 10.5614/itbj.vad.2013.4.1.5 
merely to fulfill utility needs but also as a representation of a larger scope that is the macrocosm.

Rice containers in this study include rice barn, mortar hut for processing rice and containers that made mostly by woven bamboo, created in the same form and function from generation to generation. The aim of this study is to gather the explanations of shape and form concepts and meaning of traditional design in Sundanese culture. The type of research conducted was the case study of rice containers design.

In order to find the aesthetical concept in Sundanese traditional culture that is lack of manuscript or written artifact, I used the Sundanese language as resource. According to Ajip Rosidi [2], the richness of a culture is determined by language. Language is the window that constructs the way a society observes themselves, other people and the world. In addition, language determines the boundary of width region and critical capability of a society.

Rice is the staple foods for almost all Indonesian people. There are two kinds of cultivation of rice. They are the wet rice field, which is the most common system, and the dry rice cultivation, which is mostly planted by certain traditional community such as Baduy who lives in Kanekes Banten. Meanwhile, in Sundanese, Javanese and Balinese traditional culture, rice is related to a legend or myth of rice origin influenced or derived from Hinduism mythology. Rice is believed to be created by the goddess of rice who has various names in different societies. In Sundanese, her name is "Nyi Pohaci Sang Hyang Asri" [3], while in Javanese and Balinese she is called "Dewi Sri" or "Dewi Asri". One of the myth versions explains that rice firstly grew on the grave of the "Sang Hyang Asri". In traditional ceremony in those ethnics, one of the ritual offerings is dedicated to the goddess or the rice. Thus, traditional community such as Baduy treats rice with high respect.

\section{Visual Basic Shape in Sundanese Idiom \& Proverb}

It is a common knowledge that there are three visual basic shapes in visual art: square, circle and triangle. They take the form of a cube, sphere and cone. Square does not exist in nature. Therefore, square is a human creation or a human achievement to construct visual culture. In contrary, circle and triangle, can be found in natural world. Circle can be found in the outline of the sun and the moon and in water ripples in the pond or lake. Meanwhile, triangle can be found in the form of mountain or heap of sands, as the effect of gravity.

In the proverb and idiom of Sundanese language, there are found sentences which use the visual basic shapes as symbols of perfection. Square as a symbol 
for perfection of conduct was found in sentences, such as "jelema masagi" (man with good performance) [4]. Circle for conviction appears in "niat kudu buleud" (intention must be round). Triangle is found in "buana nyungcung" (the zenith universe, a world in Sundanese cosmology for god's place) and "bale nyungcung" (house with pyramid-like roof), an idiom for perfection or holy place such as mosque.

Four equal straight sides of square symbolize aspects of life balance which is called versatile. This idiom also tells a balance between the world matter and the hereafter or the spiritual matter, which must be fulfilled in the same qualities. Circle as the symbol of conviction leads to the faith that must be served perfectly. Pyramid-like roof made by four similar triangle shapes with the pointed roof faces to the sky. The same condition with peak that faces to the sky, a place we imagine as the place of God. The triangular form derived from mountain that has play an important role in Sundanese historical map as can be seen in megalithicum sites and holy cemetery wich generally found in the mountain $[5,6]$.

Two main elements in the formal aesthetic are shape and form. Form and shape are areas or masses which define objects in space [7]. A shape is made when a line is closed and a space is enclosed. A two dimensional shape is one that is drawn on a flat surface such as a paper. A three-dimensional shape is one that takes up real space and it called form. In other words, shape is an enclosed area distinguished from its surroundings and often defined by a contour line. It has a height and width and is usually considered two-dimensional. Meanwhile, form is the organization of visual elements in three dimensions. In addition to height and width, form has actual, or the illusion of, volume or depth. Geometric forms are those which correspond to named regular shapes, such as squares, rectangles, circles, cubes, spheres, cones, and other regular forms.

\section{The Shape and Form of Traditional Rice Containers}

In Indonesian language and several Indonesian ethnic languages such as Sundanese, rice has several names based on the condition of rice. At least there are three main names. They are pare (Sundanese), padi/gabah (Indonesian), for unhulled rice; Beas (Sundanese) beras (Indonesian), for hulled rice; Sangu (Sundanese), nasi (Indonesian), for cooked rice [8].

Each condition of rice above has its certain container. In traditional Sundanese community such as Baduy with its dry rice cultivation system, rice from field dried under the sunshine and stored in rice barn called leuit which is a simple raised hut made by wood construction and walled by woven bamboo and roofed by palm leaf. There are three kinds of leuit based on their forms [9]. The oldest 
is leuit lenggang (tall leuit) (see Figure 1), karumbung (see Figure 2) and the last is gugudangan (storehouse-like) (see Figure 3).
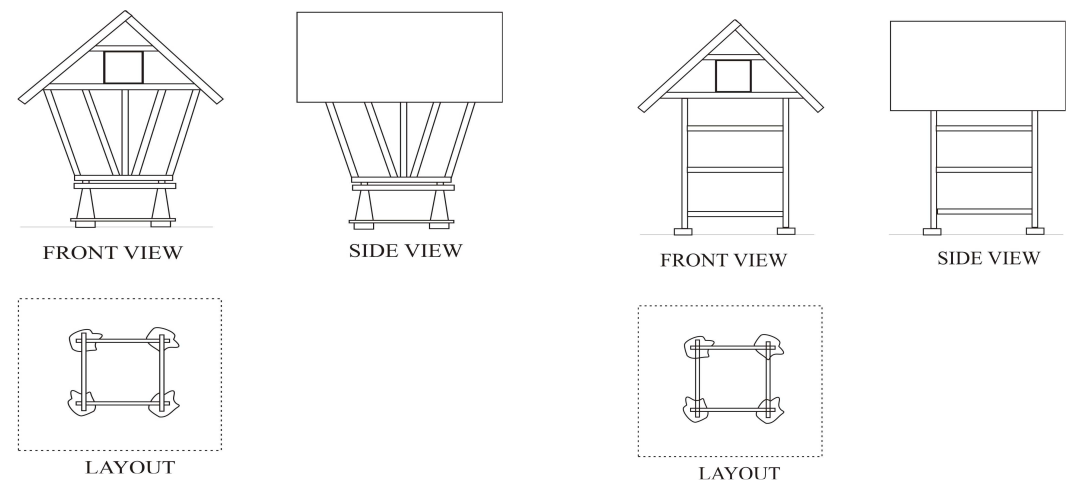

Figure 1 Leuit Lenggang/Jangkung.

Figure 2 Leuit Karumbung.

Leuit lenjang and karumbung use the square shape for layout while gugudangan use the rectangular. The square shape created cube form and in leuit lenjang the cube form transformed to a bigger form in the upper part.

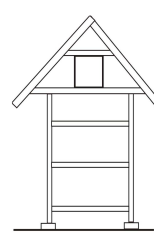

FRONT VIEW

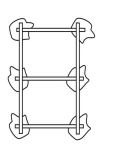

I.AYOIT

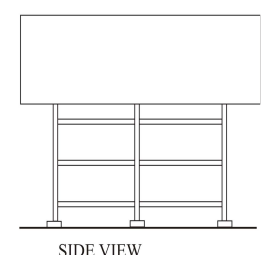

SIDE VIEW
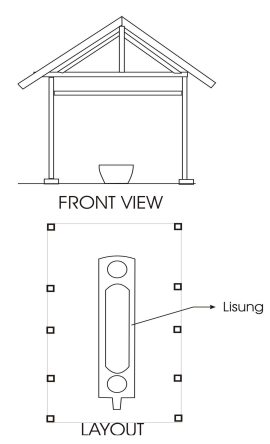

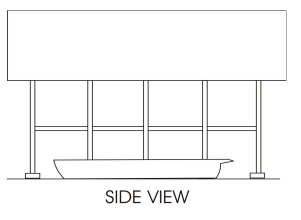

Figure 3 Leuit Gugudangan.

Figure 4 Saung Lisung.

To process the unhulled rice into hulled rice, there is lisung, a mortar to pound the un-hulled rice become hulled rice. Lisung is made of holed trunk placed in a hut names saung lisung (mortar hut). There are three holes in Baduy lisung: the larger in the center used rectangular shape with curved in each end and two 
small circles at each side of trunk. Rice pounded by rice pestle with cylinder form (see Figure 4).

To clean or separate hulled rice from husk, a tool called nyiru is used. It is a winnowing basket with circle shape. Then hulled rice placed in pabeasan, a large earthenware bowl. It takes the same form with gentong, an earthenware bowl for store water. Pabeasan is placed in goah, a foodstuff store room close to the kitchen. The form of nyiru (see Figure 5) and pabeasan are round which is created from the circle shape (see Figure 6).

Rice steaming process used kukusan (sundanese: aseupan). It is a cone form made of woven bamboo put into dandang (sundanese: langseng), a large metal vessel for steaming rice put on furnace. The form of a dandang is a combination of two cones with opposite position. The cone is made from circle shape composed from smaller size in the lower part to bigger in the upper part. The cone also created triangle shape from side view (see Figures 7 and 8).

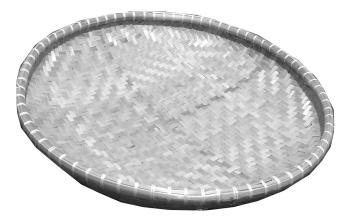

Figure 5 Nyiru, winnowing basket.

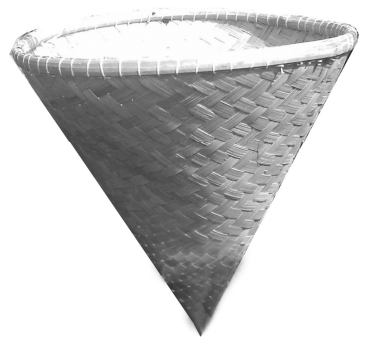

Figure 7 Kukusan.

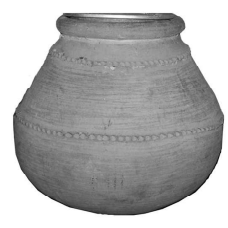

Figure 6 Pabeasan, earthenware bowl.

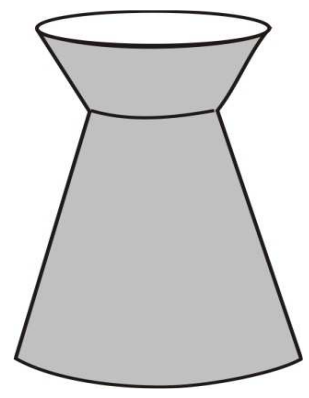

Figure 8 Dandang.

The cooked-rice in kukusan is moved to bakul (sundanese: boboko) and ready to be served into wooden plate called jahas. Bakul is the most complicated form. It 
is created from three different basic shapes at every part. At the bottom (soko) the square shape is used. Meanwhile, the middle part shows a transformation from square into perfect circle in the upper part (see Figures 9 and 10).

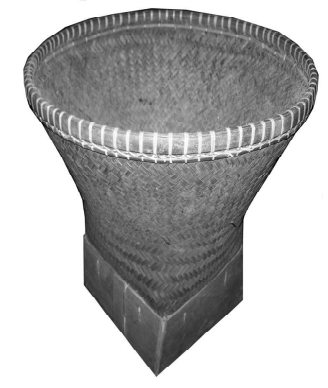

Figure 9 Boboko (rice basket).

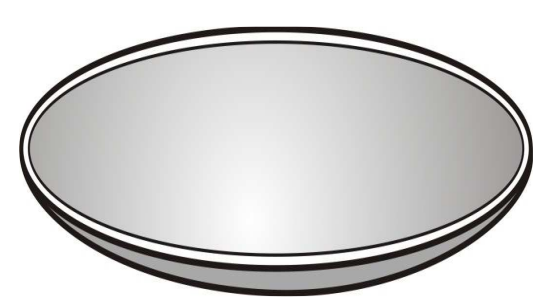

Figure 10 Jahas, wooden plate.

\section{Conclusions}

Based on the symbolical meaning of shapes in Sundanese proverb and idiom and the identification of the rice containers form, it can be concluded that those forms created not only to fulfill the utility needs and the visual pleasure of forms but also each contained an ethical message. Thus aesthetical forms contained ethical message.

The rice barn gives a message to give the best work in life (best conduct). The nyiru or the winnowing basket to separate the rice and the hull, or the content and the container and other round forms tells to fill life with a perfection of faith. Meanwhile, aseupan or kukusan shows the holy place for rice as a gift from the goddess or rice. It contains the message to place good things in the good place with a full respect.

The perfection of each part of life is shown in each shape and form. Furthermore, the whole message of life can be found in boboko that use the combination of three basic shapes. The forms also can be understood as an appreciation to the goddess of rice, the macrocosm aspects of Sundanese cosmology and also an ethical message of Sundanese cultural values.

\section{Reference}

[1] Sumardjo, J. 2000. Filsafat Seni, Penerbit ITB Bandung.

[2] Qomaruzzaman, B. 2003. Mencari Jejak Islam-Sunda, Pikiran Rakyat, 14 Agustus 2003. 
[3] Sumardjo, J. 2005. Mitos Nyi Pohaci, Pikiran Rakyat, 1 Mei 2005.

[4] Hidayat, R.T., Haerudin, D., Darpan, T.A.N.M. \& Sastramidjaja, A. 2005. Peperenian Urang Sunda, Kiblat Buku Utama, Bandung.

[5] Wessing, R. 2006. Telling the Landscape: Place and Meaning in Sunda, Prosiding Konferensi Internasional Budaya Sunda I, Bandung, Rosidi, A., Ekadjati, E.S., Alwasilah, A.C. (eds.), Yayasan Kebudayaan Rancange, 1, pp. 450-474.

[6] Fadillah, M.A. 2006. Pengultusan Orang Suci pada Masyarakat Sunda: Sebuah Kontinuitas Unsur Budaya, Prosiding Konferensi Internasional Budaya Sunda, 1, Bandung, Rosidi, A., Ekadjati, E.S., Alwasilah, A.C. (eds.), Yayasan Kebudayaan Rancage, 1, pp. 419-432.

[7] Jirousek, C., Art, Design and Visual Thinking: Form, Shape and Space, http://char.txa.cornell.edu/language/element/form/form.htm (20 April 2012).

[8] Jamaludin. 2011. Makna Simbolik Estetika Sunda: Kajian Wadah Makanan Pokok di Masyarakat Baduy, Disertasi, Program Ilmu Seni Rupa Sekolah Pascasarjana ITB.

[9] Mayasofyarni, R. 2003. Pergeseran Nilai-nilai Budaya dalam Arsitektur Kampung Baduy, Tesis, Program Magister Desain ITB. 